\title{
Perception of Sharia Banks Comparison Between Baby Boomers Generations and Millennial Generations
}

\author{
Ramlah M1, Adzan Noor Bakri², Nurmaya Fitriani Munir3 \\ Faculty of Islamic Economics and Business, Palopo State Islamic Institute \\ Palopo, South Sulawesi \\ E-mail: hjramlah@iainpalopo.ac.id
}

\begin{abstract}
,
The objectives of this study are 1) To find out the description of the perception of baby boomers about sharia banking; 2) To find out the description of millennial generation perceptions about Islamic banking; 3) To find out how to compare the perception of the two generations of Islamic banks. This writing uses a Descriptive Statistics Method that seeks to illustrate how phenomena that occur when conducting research. Data collection is done through the distribution of questionnaires/questionnaires by directly plunging into the field and given to the elderly and productive age communities. It was testing the research hypothesis using the Maan-Whitney U Test. This research shows that (1) the Baby boomers generation understands well about sharia banking, both in terms of knowledge, religiosity, profit sharing, facilities/services, and location of sharia banking. (2) Millennials better understand Islamic banking, both in terms of knowledge, religiosity, profit sharing, facilities/services, and location of Islamic banking. However, after testing the hypothesis, it was found that there were no differences in the perceptions of the two generations.
\end{abstract}

Keywords: Perceptions, Baby boomers, Millenials, Islamic bank

\section{INTRODUCTION}

It has been almost two decades; Islamic banks are present in Indonesia. The bank, which is perceived as a bank with the concept of profit sharing and interestfree, apparently cannot grow in a country with the largest Muslim population. According to (Husen Miftahudin, 2020), in April 2020, the Islamic banking market share has increased to 9 percent. This data shows that of the approximately 250 million Indonesian population, only 9 percent use Islamic banks and financial institutions. This reality shows that there is a low level of public awareness to interact with Islamic banks. This reality is not in line with many arguments that Islamic banks will increase in a country with a Muslim majority population.

The decision process for customers to choose Islamic banks involves their perceptions or views of Islamic banks. So far, many studies have described how the public perceives Islamic banks. The quality of Islamic banking as a whole is influenced by perceptions of the quality of results (Wu et al., 2019). (Jannah \& Arry Widodo, 2018) revealed that customer perceptions of Islamic banks have an impact on customer satisfaction and customer switching intention. The quality of service provided by Islamic banks is considered to satisfy their customers. However, they have not been able to meet their expectations because there are still performances that are considered less able to satisfy customers (Iffah, 2018). Islamic bank customers have a unique and complex behavior to understand. As a service provider industry, Islamic banks are required to provide banking services based on their customers' characteristics. Unlike previous studies that tended to focus on examining the influence of customer perceptions on service quality, satisfaction to loyalty, this 
study focuses more on customer perceptions seen from two different generation groups, namely the baby boomers and millennial generations.

The two groups of this generation have different characters in buying (Dorie \& Loranger, 2020). The baby boomer generation lived between 1946 and 1964 (Parment, 2013), while the millennial generation is people who lived after the baby boomer generation, namely between 1981 and 1994 (Aikat, 2019). When viewed from this information, the two generations have different perceptions of Islamic banks. Each generation also has its character in shopping. The baby boomers generation is the generation that most often spends their money on wasteful things.

In contrast, the millennial generation is a generation inhabited by humans who have faced a great recession, tend to be less fortunate than their parents (Dorie \& Loranger, 2020). The millennial generation also ranges to income. They often look for discounts before deciding to buy a product. When viewed in terms of revenue and assets, the millennial generation has far less income and assets than the baby boomers generation (Dorie \& Loranger, 2020). This difference in behavior underlies the suspicion of this study that there are differences in perceptions between the baby boomers and the millennial generations of Islamic banks. This study describes the perception map of the two segments of the Islamic banking market so that it can be used to provide services by the characteristics of Islamic bank customers by generation.

\section{LITERATURE REVIEW}

Several researchers have provided an overview of what kind of public perception of Islamic banks. (Belwal \& Al Maqbali, 2019) found that people in Oman have different opinions about Islamic banks. Some of the customers of Islamic banks in Oman are not sure that Islamic banks are implementing Islamic principles, so they have not decided to open an account. The same thing was stated by (Shabbir \& Rehman, 2019), which revealed the perception of conventional economists who view Islamic banks as not fully applying sharia principles to products that have been released to the market. The study from (Butt et al., 2018) also reveals that both customers and non-customers of Islamic banks understand that Islamic banks are not entirely free of interest. Adherence to Islamic law (Sharī'ah compliance) does have a significant moderating effect between the effect of customer perceptions on customer satisfaction in Pakistan (Saqib et al., 2016). The same thing was stated by (Hosen et al., 2019) that Islamic compliance is a crucial service variable in Islamic banks. This occurs because the level of knowledge of Islamic banks in each segment of society is different, even though (Shabbir \& Rehman, 2019) reveals that knowledge can synthesize good and positive perceptions of Islamic banks. When viewed from a banker's point of view, it is found that bankers have clear opinions and ideas about Islamic banks (Riaz, Burton, et al., 2017a) (Riaz, Burton, et al., 2017a). Even so, not all Islamic bank bankers have good knowledge of Islamic sharia related to transactions in Islamic banks (Riaz, Burton, et al., 2017a). This is confirmed by (Riaz, Burton, et al., 2017b), which states that knowledge has a significant influence on perceptions of Islamic banks. 
Perceptions of Islamic banks are also seen from physical aspects such as service quality, price, and transparency for profit sharing (Iffah, 2018). An exploration from (Chaouch 2017) reveals that there is a positive public perception of Islamic banks, but dissatisfaction with the transparency of profit-sharing is found in some customers. When compared to conventional banks, Islamic bank customers have an attitude of service quality that is much better than traditional bank customers (Ali, 2018), Islamic bank customers perceive physical evidence and guarantees as to the most significant components of service quality, while conventional bank customers perceive guarantees. And innovation as the most considerable component of service quality. The perception of costs also does not escape the consideration of customers when choosing an Islamic bank. The reason for getting low administrative costs. This is different when compared to the reasons customers choose conventional banks, which are more due to the availability of affordable ATM facilities (Wulandari \& Subagio, 2015).

The aspect of customer religiosity also influences perceptions of Islamic banks (Riaz, Khan, et al., 2017). a study conducted by (Riaz, Burton, et al., 2017b) revealed that apart from knowledge, customer religiosity also has a significant impact on perceptions of Islamic banks in Pakistan. Customer religiosity does play an essential role in the decision process for customers to choose Islamic banks. According to (Zuhirsyan \& Nurlinda, 2018), partially religiosity is more influential on the decision to choose a sharia bank than perception. In the case in Afghanistan (Safi et al., 2020) found that customer choice of Islamic bank products is influenced by the variable of religiosity (religious belief). The same thing was also found in Indonesia by (Reni \& Ahmad, 2016), which stated that in addition to variables such as subject norms, knowledge, and government support, religion also has a significant influence on people's intention to choose Islamic banks. Another finding was revealed by (Butt et al., 2018), who said that the religiosity factor was not a variable that could attract people who would adopt Islamic banks.

Ethical perceptions will generate interest in choosing Islamic banks. Based on studies from (Imran \& Hendrawan, 2018) and (SAPUTRA \& KHOIRUL ANWAR, 2019) that when perceptions about Islamic banks (perceptions of bank interest, and profit-sharing) increase, it will increase interest in choosing Islamic banks. This finding is in line with what was expressed by (Zuhirsyan \& Nurlinda, 2018) that religiosity and perception simultaneously (together) have a positive impact on the decision to choose a sharia bank. Ethical perceptions will also impact the customer switching intention of Islamic Banks (Jannah \& Arry Widodo, 2018).

Based on a review of some of the studies above, the authors did not find any specific studies discussing the comparison of perceptions across generations. A comparison of perceptions is only found in studies of customers of conventional banks and Islamic banks, Muslim and non-Muslim customers, and studies of bank customers and bank employees. Researching different perceptions across generations, especially the baby boomers and millennial generations, will be an addition to creating segmentation maps, determining product targets, and positioning the right products according to each generation's characteristics. 


\section{METHODS}

Library ReviewThe type of research used is quantitative research with descriptive methods. This research was carried out in the sub-district of the tip of Parepare City. Because researchers saw several Islamic banks opened in the city of Parepare, this is what makes researchers interested in analyzing the comparison of the perceptions of the baby boomers generation and the millennial generation about Islamic banking. The population in this study were all people who were born and lived between 1946-1964 for baby boomers and those who were born and lived between 1980 and 1994 for the millennial generation in Ujung District, Parepare City. The sampling technique in this study used a probability sampling technique, namely, area sampling. Area sampling technique is used to determine the sample if the object to be studied or the data source is extensive and scattered. In the sense that the sampling area is carried out by taking representatives from each existing region. Therefore, the researchers planned to take a sample of 100 people, namely 50 from each generation.

In this study, the data collection technique used by researchers was a questionnaire (questionnaire). The alternative answer will use a 5-point Likert scale. The 5-point Likert scale is taken as the benchmark for all statement items on the rating scale. Therefore, in this 5-point Likert scale, the respondents' reasons will be given a statement item with a choice of self-assessment of the respondent between 1 to 5 intervals. Figures $1-5$ are based on favorable and unfavorable items. For favorable items, the answers to $\mathrm{SS}=5, \mathrm{~S}=4, \mathrm{~N}=3, \mathrm{TS}=2$, STS $=1$ For unfavorable items, answer $\mathrm{STS}=5, \mathrm{TS}=4, \mathrm{~N}=3, \mathrm{~S}=2, \mathrm{SS}=1$.

We are analyzing the contents of the research data using descriptive and inferential statistical techniques.

1. Descriptive statistics provide an overview of the sample data of the research variables, namely, mean, median, mode, standard deviation, variance, skewness, kurtosis, minimum range, maximum range, and percentage analysis. Scoring is related to scaling, in which scaling is the process of locating response categories on a psychological continuum.

Besides, the scaling process focuses on the characteristics of the numbers, which are the scale values. A score on a psychological scale determined by the procedure will result in a score on the level or measurement level.

Lowest score $\leq X<\mu-1,5(\sigma)$

$$
\begin{aligned}
& \mu-1,5(\sigma) \leq X<\mu-0,5(\sigma) \\
& \mu-0,5(\sigma) \leq X<\mu+0,5(\sigma) \\
& \mu+0,5(\sigma) \leq X<\mu+1,5(\sigma) \\
& \mu+1,5(\sigma) \leq X \leq \text { skor tertinggi }
\end{aligned}
$$

deficient category

low category

moderate category

high category

very high category

Where, $\mu=$ skor terendah $\times 3$

$$
\sigma=\frac{\text { skor tertinggi-skor terendah }}{6}
$$

2. Inferential statistics are intended for analysis and validation of the proposed model as well as testing hypotheses 
Hypothesis testing using a different test (Sample T-Test) is used if the data collected meets the normality assumption. By using a formula:

$$
t=\frac{X 1-\underline{X 2}}{\sqrt{\frac{S 1^{2}}{n_{1}}+\frac{S 2^{2}}{n_{1}}}}
$$

Hypothesis testing using the Maan Whitney U Test is a non-paramatric test option if the Independent $\mathrm{T}$ test cannot be performed because the assumption of normality is not met. However, apart from the non-parametric form of the test, the Mann Whitney U Test did not test for differences in the two groups as an independent test, but to test for differences in the median (mean value) of the two groups. This hypothesis test uses the SPSS version 22 statistical tool

\section{DISCUSSION}

\section{Perception of the Baby Boomers Generation of Islamic Banking Syariah}

Table 1 Distribution of Baby Boomers Generation Perception Score about Islamic banking.

\begin{tabular}{lllll}
\hline No & Score & Frequency & $\begin{array}{l}\text { Percentag } \\
\mathrm{e}(\%)\end{array}$ & Category \\
\hline 1 & $24 \leq P M<48$ & 0 & 0 & Not very good \\
2 & $48 \leq P M<64$ & 0 & 0 & Not good \\
3 & $64 \leq P M<80$ & 32 & 64 & Moderate \\
4 & $80 \leq P M<96$ & 15 & 30 & Well \\
5 & $96 \leq P M<120$ & 3 & 6 & Very good \\
\hline & total & 50 & 100 & \\
\hline Mean & Std.Deviasi & Variansi & Minimum & Maksimum \\
\hline 78,76 & 8,752 & 76.594 & 65 & 104 \\
\hline
\end{tabular}

Table 1 shows that the average perception score of the elderly about Islamic banking in Ujung Subdistrict, Parepare City is 78.76 from an ideal score of 120, which means that the perception of the advanced community about Islamic banking is in the moderate category. Table 1 above shows that 15 people are in the excellent category, three people are in the outstanding category

\section{Perception of Millennial Generation on Islamic Banking}

Table 2 shows that the average perception score of the productive age community about Islamic banking in Ujung Subdistrict, Parepare City is 82.34 from an ideal score of 120 , which means the perception of the productive community about Islamic banking is in a proper category. Table 4.2 above shows that one person is in the wrong category, 24 people are in the medium category, and nine other people are in an outstanding category. 
Table 2. Distribution of Perception Score of Productive Age Society about Islamic banking di Kota Parepare

\begin{tabular}{lllll}
\hline No & Score & Frequency & Percentage (\%) & Category \\
\hline No & Skor & Frekuensi & Persentasi (\%) & Kategori \\
\hline 1 & $24 \leq P M<48$ & o & o & Not very good \\
2 & $48 \leq P M<64$ & 1 & 2 & Not good \\
3 & $64 \leq P M<80$ & 24 & 48 & Moderate \\
4 & $80 \leq P M<96$ & 16 & 32 & Well \\
5 & $96 \leq P M<120$ & 9 & 18 & Very good \\
\hline \multirow{2}{*}{ Mean } & Total & 50 & 100 & Maksimum \\
\hline 82,34 & 5,308 & Variansi & Minimum & 110 \\
\hline
\end{tabular}

\section{Hypothesis Testing}

The hypothesis test used in this study is the Mann-Whitney U Test, a nonparametric independent 2 sample difference test because the perception data of the elderly and productive age community are generally not distributed. The hypothesis in this study are:

Ho $=$ There is no difference in the perception of millennial baby boomers about Islamic banking.

$\mathrm{H} 1=$ There are differences in perceptions of baby boomers and millennials about Islamic banking.Hasil analisis uji hipotesis dapat dilihat pada Tabel $4.5 \mathrm{di}$ bawah ini.

Table 3. Maan Whitney Test

\begin{tabular}{|l|l|}
\hline & Skor \\
\hline Mann-Whitney U & 1022.500 \\
Wilcoxon W & 2297.500 \\
Z & -1.570 \\
\hline Asymp. Sig. (2-tailed) & .116 \\
\hline
\end{tabular}

a. Grouping Variable: Usia

The basis for the decision to test the hypothesis if the significant value (sig) $<0.05$ then Ho is rejected $\mathrm{H} 1$ is accepted. Based on the table above, it can be seen that the significance value is $0.116>0.05$; this shows that Ho is accepted, and $\mathrm{H} 1$ is rejected, meaning that there is no difference in perceptions between the baby boomers generation and the millennial community about Islamic banking.

\section{Discussion}


The description of the perception of the baby boomers generation about Islamic banking is in table 1 , there are no people who have a terrible perception, and there are also no baby boomers who have a terrible perception of Islamic banking. There are 32 people in the medium category, 15 people in the first category, and three in the outstanding category. In general, the overall perception of the elderly about Islamic banking is 78.76 in the medium category. This shows that the baby boomers community's perception is quite excellent in terms of knowledge, religiosity, profit sharing, services, and facilities, as well as the location of Islamic banking.

The baby boomers generation has mature considerations in looking at Islamic banks. The buying process carried out by the baby boomers generation starts from a belief in a product or company (Parment, 2013). This age group has high esteem and more experience than other generations, such as the millennial generation. The baby boomers generation also based their choices on product quality. This group is susceptible to the quality of a product because it has a better thinking maturity level. It was stated by (Kumar \& Lim, 2008) that as people get older, they will not accept innovations such as technological innovation. If based on this argument, the baby boomers generation will not have a good perception of Islamic banks due to conventional thinking, but the baby boomers are users of modern technology. They have greater access to the internet than the adult population as a whole. It can be said that this market segment has great potential to adopt Islamic banks when viewed from the maturity of thought and full consideration.

The baby boomers generation has mature considerations in looking at Islamic banks. The buying process carried out by the baby boomers generation starts from a belief in a product or company (Parment, 2013). This age group has high esteem and more experience than other generations, such as the millennial generation. The baby boomers generation also based their choices on product quality. This group is susceptible to the quality of a product because it has a better thinking maturity level. It was stated by (Kumar \& Lim, 2008) that as people get older, they will not accept innovations such as technological innovation. If based on this argument, the baby boomers generation will not have a good perception of Islamic banks due to conventional thinking, but the baby boomers are users of modern technology. They have greater access to the internet than the adult population as a whole. It can be said that this market segment has great potential to adopt Islamic banks when viewed from the maturity of thought and full consideration.

The description of the perceptions of the millennial generation about Islamic banking in table 2, there are no people who have a terrible perception of Islamic banking, and there is one person who has a wrong perception of Islamic banking. As for those in the medium category, there were 24 people, 16 people in the first category, and nine people in the outstanding category. Overall, the overall perception of Islamic banking's millennial generation is 82.34, which is in the first category. This shows that the perception of the millennial generation of society has understood well in terms of knowledge, religiosity, profit sharing, sharia banking services and facilities, and the location of sharia banking. 
Unlike the baby boomers generation who seem consumptive, the millennial generation is a generation that is very familiar with technology and depends on social media (Aikat, 2019) (Dorie \& Loranger, 2020). This causes the mindset and perspective of this generation to be easily influenced by information spread on social media. Compared to other generations, the millennial segment has a more substantial interest in the convenience that cyberspace provides. Millennials enjoy how easy news is on social media platforms that they use for social interactions, around $21 \%$ of people say that convenience is their favorite thing about social media as a news source (Michael, 2019). The perceptions given by the millennial generation in this study are mostly based on the knowledge they get from social media. Millennials' knowledge about Islamic banks, such as the compliance aspect of sharia, is mostly obtained from their social media interactions such as websites and YouTube.

The hypothesis test results show that there is no significant difference in perceptions between baby boomers and millennial generations about Islamic banks. If you look at previous studies, these two generations do have different channels of information, but their knowledge still influences perceptions about Islamic banks. For example, these two generations both have a good understanding of the appropriateness of sharia, but when they interact with Islamic banks and find something that is not by what they understand, negative perceptions will arise. Segmentation of customers by generation is proper, but it must be remembered that people obtain information according to their habits. Any information that enters their brains will be stored in the customer's black box. The task of Islamic banks is accessing the black box, then finding a formula to translate it. There are many limitations to the results of this study. The results of this study only focus on providing an overview of Islamic banks how the perceptions of two generations living in different times. This study is also limited to one area only, with a very minimal number of respondents. Therefore it is hoped that there will be other more comprehensive studies to provide a map of people's perceptions of Islamic banks..

\section{CONCLUSION}

Based on the phenomenon, a review of the literature, methods, and results obtained, the conclusions of this study are. The perception of the baby boomers generation about Islamic banks is in the medium category, while the millennial generation's perceptions about Islamic banks are in a proper category. There were no significant differences between the perceptions of the baby boomers and millennials about Islamic banks.

\section{REFERENCES}

Aikat, D. (2019). Millennials Usher a Post-Digital Era: Theorizing how Generation $Y$ Engages with Digital Media. 19, 9-29. https://doi.org/10.1108/s2050206020190000019002

Ali, Q. (2018). Service Quality from customer perception: Comparative analysis between Islamic and conventional bank Service Quality from Customer 
Perception : Comparative Analysis between Islamic and Conventional Bank. Journal of Marketing and Consumer Research, 43(1), 2422-8451.

Belwal, R., \& Al Maqbali, A. (2019). A study of customers' perception of Islamic banking in Oman. Journal of Islamic Marketing, 1O(1), 150-167. https://doi.org/10.1108/JIMA-02-2016-0008

Butt, I., Ahmad, N., Naveed, A., \& Ahmed, Z. (2018). Determinants of low adoption of Islamic banking in Pakistan. Journal of Islamic Marketing, 9(3), 655-672. https://doi.org/10.1108/JIMA-01-2017-0002

Chaouch, N. (2017). An Exploratory Study of Tunisian Customers' Awareness and Perception of Islamic Banks. Uluslararası Íslam Ekonomisi ve Finansı Araştırmaları Dergisi, 3(2), o-o. https://doi.org/10.25272/j.21498407.2017.3.2.01

Dorie, A., \& Loranger, D. (2020). The multi-generation: Generational differences in channel activity. International Journal of Retail and Distribution Management, 48(4), 395-416. https://doi.org/10.1108/IJRDM-06-20190196

Hosen, M. N., Lathifah, F., \& Jie, F. (2019). Perception and expectation of customers in Islamic bank perspective. Journal of Islamic Marketing. https://doi.org/10.1108/JIMA-12-2018-0235

Husen Miftahudin. (2020). Pangsa Pasar Keuangan Syariah Naik Jadi 9,o3\% di April 202O. Https://Www.Medcom.Id/Ekonomi/Keuangan/GKdOxe4kPangsa-Pasar-Keuangan-Syariah-Naik-Jadi-9-O3-Di-April-2020.

Iffah, L. (2018). Persepsi Nasabah Terhadap Tingkat Kualitas Pelayanan Bank Syariah Cabang Malang. FALAH: Jurnal Ekonomi Syariah, 3(1), 79. https://doi.org/10.22219/jes.v3i1.5836

Imran, I., \& Hendrawan, B. (2018). Pengaruh Persepsi Masyarakat Batam Tentang Bank Syariah Terhadap Minat Menggunakan Produk Bank Syariah. Journal of Applied Business Administration, 1(2), 209-218. https://doi.org/10.30871/jaba.v1i2.621

Jannah, A. M., \& Arry Widodo. (2018). PENGARUH PERSEPSI BANK SYARIAH DI INDONESIA TERHADAP CUSTOMER SWITCHING INTENTION DENGAN CUSTOMER SATISFACTION SEBAGAI MEDIATOR Anisa. JURNAL SEKRETARIS \& ADMINISTRASI BISNIS Jurnal, II(1), 41-50.

Kumar, A., \& Lim, H. (2008). Age differences in mobile service perceptions: Comparison of Generation $\mathrm{Y}$ and baby boomers. Journal of Services Marketing, 22(7), 568-577. https://doi.org/10.1108/08876040810909695

Michael, D. (2019). Where Millennials end and Generation Z begins | Pew Research Center. Pew Research Center, 1-7. https://www.pewresearch.org/facttank/2019/o1/17/where-millennials-end-and-generation-z-begins/

Parment, A. (2013). Generation Y vs. Baby Boomers: Shopping behavior, buyer involvement and implications for retailing. Journal of Retailing and Consumer Services, 2O(2), 189-199. https://doi.org/10.1016/j.jretconser.2012.12.001

Reni, A., \& Ahmad, N. H. (2016). Application of Theory Reasoned Action in Intention 
To Use Islamic Banking in Indonesia. Al-Iqtishad: Journal of Islamic Economics, 8(1), 137-148. https://doi.org/10.15408/aiq.v8i1.2513

Riaz, U., Burton, B., \& Monk, L. (2017a). Perceptions on Islamic banking in the UKPotentialities for empowerment, challenges and the role of scholars. Critical Perspectives on Accounting, 47, 39-60. https://doi.org/10.1016/j.cpa.2016.11.002

Riaz, U., Burton, B., \& Monk, L. (2017b). Perceptions on the accessibility of Islamic banking in the UK-Challenges, opportunities and divergence in opinion. Accounting Forum, 41(4), 353-374. https://doi.org/10.1016/j.accfor.2017.10.002

Riaz, U., Khan, M., \& Khan, N. (2017). An Islamic banking perspective on consumers' perception in Pakistan. Qualitative Research in Financial Markets, 9(4), 337358. https://doi.org/10.1108/QRFM-03-2017-0020

Roberts, J. A., \& Manolis, C. (2000). Baby boomers and busters: An exploratory investigation of attitudes toward marketing, advertising and consumerism. Journal of Consumer Marketing, 17(6), 481-497. https://doi.org/10.1108/o7363760010349911

Safi, L., Abbey, B., Goucha, N. B. S., Serhan, O. Al, \& Gleason, K. (2020). Knowledge of Islamic banking and bank customer satisfaction in Afghanistan: An exploratory analysis. International Journal of Business Performance Management, 21(1-2), 21-38. https://doi.org/10.1504/IJBPM.2020.106104

SAPUTRA, H., \& KHOIRUL ANWAR, M. (2019). Pengaruh Persepsi Mahasiswa Program Studi Non Ekonomi Islam Terhadap Minat Menjadi Nasabah Bank Syariah. Jurnal Ekonomi Islam, 2(1), 1-9.

Saqib, L., Farooq, M. A., \& Zafar, A. M. (2016). Customer perception regarding Sharī'ah compliance of Islamic banking sector of Pakistan. Journal of Islamic Accounting and Business Research, $7(4), \quad 282-303$. https://doi.org/10.1108/JIABR-08-2013-0031

Shabbir, M. S., \& Rehman, A. (2019). Layers of misconceptions about Islamic banking: Are Islamic banks threats, challenges and opportunities for investors? Journal of Islamic Marketing, 1O(3), 874-892. https://doi.org/10.1108/JIMA-02-2018-0026

Wu, H. C., Cheng, C. C., \& Hussein, A. S. (2019). What drives experiential loyalty towards the banks? The case of Islamic banks in Indonesia. International Journal of Bank Marketing, 37(2), 595-620. https://doi.org/10.1108/IJBM04-2018-0101

Wulandari, D., \& Subagio, A. (2015). Consumer Decision Making in Conventional Banks and Islamic Bank based on Quality of Service Perception. Procedia Social and Behavioral Sciences, 211(September), 471-475. https://doi.org/10.1016/j.sbspro.2015.11.062

Zuhirsyan, M., \& Nurlinda, N. (2018). Pengaruh Religiusitas dan Persepsi Nasabah terhadap Keputusan Memilih Bank Syariah. Al-Amwal : Jurnal Ekonomi Dan Perbankan Syari'ah, 1O(1), 48. https://doi.org/10.24235/amwal.v10i1.2812 